\title{
The university and metropolitan planning: an innovative experience
}

\author{
Universidade e planejamento metropolitano: uma experiência inovadora
}

\author{
Roberto Luís de Melo Monte-Mór \\ Universidade Federal de Minas Gerais \\ Geraldo Magela Costa \\ Universidade Federal de Minas Gerais \\ Heloisa Soares de Moura Costa \\ Universidade Federal de Minas Gerais
}

Marcos Gustavo Pires de Melo

Universidade Federal de Minas Gerais

\begin{abstract}
The Federal University of Minas Gerais (UFMG) has been carrying out an experience of metropolitan planning in Belo Horizonte, Brazil, since 2009, involving a significant number of faculty and students. In this paper, we highlight some of the innovative aspects of this planning process. We stress the specificities of a planning experience conducted under the auspices of the University in an attempt to move beyond both its disciplinary and academic boundaries. Therefore, we emphasize the participatory dimension in which the University team is engaged along with civil society. We also describe proposals that put the environmental concern at the forefront of metropolitan restructuring and the efforts to materialize them through a Green and Blue Weft (Trama Verde e Azul - TVA). Finally, we discuss our understanding of planning as a political process beyond the institutionalized public policy practice in an attempt to give voice and visibility to different ways of seeing and making the metropolitan region.
\end{abstract}

\section{Keywords}

metropolitan planning; university; transdisciplinarity; citizenship and politicization.

JEL Codes H77; O20; R50; R58.

\section{Resumo}

A Universidade Federal de Minas Gerais (UFMG) vem conduzindo uma experiência de planejamento metropolitano em Belo Horizonte, Minas Gerais, Brasil, desde 2009, envolvendo um número significativo de professores e alunos. Neste artigo, chamamos a atenção para alguns aspectos inovadores desse amplo processo de planejamento. Ressaltamos as especificidades do processo de planejamento conduzido no âmbito da universidade, em uma tentativa de superar fronteiras disciplinares e acadêmicas. Assim, enfatizamos a dimensão participativa desse processo de planejamento no qual a equipe da UFMG se engajou junto com a sociedade civil. Também descrevemos as propostas que colocam a preocupação ambiental no centro da reestruturação metropolitana e os esforços para materializá-las através da Trama Verde e Azul (TVA). Finalmente, discutimos nosso entendimento do planejamento como processo político situado para além das práticas institucionais, como uma tentativa de garantir voz e visibilidade a diferentes modos de ver e produzir o espaço social metropolitano.

\section{Palavras-chave}

planejamento metropolitano; universidade; transdisciplinaridade; cidadania e politização.

Códigos JEL H77; O20; R50; R58. 


\section{Introduction}

In this paper, we reflect on an experience of metropolitan planning in Belo Horizonte, Minas Gerais, Brazil, carried out by the Federal University of Minas Gerais (UFMG), Brazil, involving a significant number of faculty members and students. This experience begun in 2009 when, in 18 months, a team of 50 professors and 80 graduate and undergraduate students, and some independent consultants, designed the Integrated Development Metropoli$\tan$ Plan (PDDI) for the Metropolitan Region of Belo Horizonte (RMBH) ${ }^{1}$. In 2013, a proposition for metropolitan land use and occupation - the Metropolitan MacroZoning (MZ) - followed that work, involving circa 90 professors and students ${ }^{2}$. At this point, the same team is working on the Revision of the Master Plans (PDs) of eleven among the 34 metropolitan municipalities ${ }^{3}$. In this paper we will highlight some aspects of this broad planning process.

These have been extremely rich experiences, based on critical theories and innovative participatory interdisciplinary - rather, transdisciplinary approaches ${ }^{4}$. It has implied a process of rethinking and transcending the principles and methodologies of a relatively consolidated urban reform process that began in the late 1980s, with the end of Brazil's 21-year military dictatorship. We can say that such an advancement, or transcendence, occurred according to at least four different complementary points, used here as structuring parts for this article, and presented as follows.

First, after a brief review of Brazil's recent history of urban and metropolitan planning and social mobilization, we introduce the innovative university planning process that involved UFMG's students and faculty in a "learning

1 The Metropolitan Region of Belo Horizonte (RMBH) was created in 1973 and corresponds to 34 municipalities forming an urban agglomeration of around five million inhabitants, half of them concentrated in the capital. It accounts for $25 \%$ of Minas Gerais population and one third of the state's GDP. Located in the Brazilian Southeast, the region, together with Rio de Janeiro and São Paulo, represent the most important concentration of industrial production and urban population in the country.

2 Minas Gerais State's Sub-Secretary for Metropolitan Affairs, authorized by Metropolitan Development Council and using resources from the Metropolitan Development Fund, hired a university foundation - IPEAD/Face/UFMG - to elaborate the PDDI-RMBH. The following contracts - the MZ-RMBH and the current Revision of Municipal Master Plans (PDs) - followed the same institutional and financial pattern.

3 PDs should translate at local level the propositions contained in RMBH's PDDI and MZ.

4 By transdisciplinary we mean an approach that transposes disciplinary boundaries to drive participants beyond their own academic disciplines into embracing other theoretical perspectives, analytical methods, and critical appraisals mostly linked by territorial, political and socioenvironmental issues. 
by doing" process where planning methodology is collectively constructed along the development of studies and propositions. It meant moving from "social reform" to "social learning" (including "social mobilization"), , understanding that it is mandatory to consider participation as inherent to a democratic process of metropolitan planning and governance, the latter understood as social control in search for radical changes and emancipation.

Second, we emphasize the University central critical premises and the perspective of continuity within the whole process, meaning a permanent involvement of the University in metropolitan planning as part of educational activities involving research and extension. The central objective is to produce information and to develop social and political mobilization in close interaction with municipal and metropolitan governance instances and social movements.

Third, we introduce the environmental dimension in many policies, and particularly as an innovative territorial analysis, which means to consider water, green areas and culture as fundamental as urban land and built environment themselves in the process of metropolitan territorial (re)structuring. Consequently, it also becomes an essential issue to consider in urban planning and regulation.

Fourth, we understand planning not merely as a technical process, but as a political one. In this sense we emphasize the role and the importance of political actors and actions that go far beyond the institutionalized practice in an attempt to give voice and visibility to different ways of seeing and making the metropolitan - not rarely in contradiction with traditional - planning. This demands new concepts, new spaces and new articulations that impose on the university the need to rethink its epistemologies and its political role to become the realm of new possibilities that arise from a critical perspective of planning and production of the metropolitan space.

\section{Metropolitan planning, political participation and social control in Brazil - a review}

Urban planning in Brazil, at least in the academic milieu and social movement's actions, has been considered a way of proposing structural 5 Reference to John Friedmann's (1987) classification of 'planning traditions' over 200-year history of planning theory. 
sociospatial changes ever since the 1960s, when urban problems became a central matter of concern. The most challenging urban problem in Brazil can be very briefly defined as a historical and persistent process of sociospatial exclusion and dispossession. From those days, the idea that has guided planners' propositions was urban reform, which includes the belief that a democratic state could be the main agency to lead a process of building a socially just city. However, Brazil lived under a dictatorship from 1964 to 1985, when those who fought for an urban reform (planners, intellectuals and social movements ${ }^{\circ}$ ) redirected their mobilizing forces against the military regime and its centralized and authoritarian urban policies. By the end of the 1970s, the rise of urban social movements brought a new breach to the idea of urban reform, implying the need to restore democracy.

It can thus be said that the eighties represented a period of political transition in Brazil after military rule, and the transition to civilian government was rather tragic and disappointing ${ }^{7}$. Economic crises produced uncertainties and the state also became financially weaker.

Despite that, all movements related to the urban question led by intellectuals and the organized civil society, particularly those proposing an urban reform geared toward the construction of a legal system of land use and occupation that recognized the "social function of urban property (land) and the city", came together under the belief that a democratic state could accept a proposal of popular amendment for the Constitution. This was certainly a follow up to the same kind of thinking from the late 1970s that emphasized democracy and state reforms as a condition to achieve a socially effective urban reform.

In fact, the new Constitution issued in 1988 incorporated several principles and proposals from the abovementioned popular amendment, meaning that a new kind of urban reform had finally begun in Brazil. The Constitution restored local autonomy and emphasized municipal responsibilities for "urban development policies". The central point of those

6 It should be stressed that, although Brazil has a long tradition and experience in urban and regional planning, the planning profession is not regulated nor recognized in the country, being planners all those who, coming from many areas of knowledge, get involved in the planning process.

7 The first elected civil president, a liberal, died just before taking office. The vice-president was a representative of the Brazilian oligarchies, which led to difficulties in introducing political and social changes. Nevertheless, social mobilization guaranteed the drawing of a progressive new Constitution. 
policies was the need for cities and towns, and urban property in general, to fulfil a social function, meaning that all urban legal and administrative policy initiatives should pursue such an objective. The culmination of the process of constructing a set of legal instruments to achieve the "social function of urban property and cities" came with the Statute of the City, in 2001. This major piece of urban legislation became a lifesaver, and made it mandatory the participation of civil society in all moments and instances of urban planning and governance. Municipal master plans became thus the main instruments to guide the application of all other instruments aiming at the social function of urban properties and cities.

However, despite some democratic advances in decentralization and participation processes, whereby some local governments elected by progressive parties tried to construct new and more democratic forms of urban governance, Brazil was under certain constraints that hit several developing countries since the 1990s. Those constraints are partly due to the globalization process and neoliberal ideology leading municipalities to adopt types of strategic planning aiming primarily at integrating local areas into a globalized economy, and consequently, jeopardizing that nascent democratic character of urban planning. In addition, several evaluations identified that popular participation through deliberative or consultative councils created within that 'new' urban planning was far from constituting an actual process of social control becoming in many cases, just an instrument to legitimate governmental authoritarian decisions.

Nevertheless, neither the 1988 Constitution nor the Statute of the City legislated on the metropolitan issue, one of the most centralized territorial policies during the military regime. In 1973/74, nine metropolitan regions were created, including the Metropolitan Region of Belo Horizonte $(\mathrm{RMBH})$, our object of analysis. The military government, however, was much more concerned with a modernizing territorial policy to provide general conditions of production to support economic growth than with socio-political urban and metropolitan problems as stated above.

In the RMBH, Plambel, a metropolitan planning institution, was created in 1974. ${ }^{8}$ Its activities were supposedly controlled by two committees: one delib-

8 Our intention here is not to present all achievements and problems related to that period of metropolitan planning - from 1974 to the end of the 1980s - but simply make some comments on the way participation was considered, and inquire if it could be identified as a process of social control over metropolitan planning and management. 
erative and the other, consultative. However, both committees were - given their composition and the way their members were appointed - under the effective control of Minas Gerais state government. The civil society was not represented in the committees and, according to Azevedo and Rennó (2003, p. 216), they were "barely called to give 'legal' support to the decisions taken by Plambel". Even if those committees were effective, this would not necessarily mean social control, but just a way to legitimate decisions already taken.

Since the beginning of the re-democratization process in the mid-1980s, this kind of centralized metropolitan policy and planning slowly decayed, and it was officially vanished in the late 1990s. By the early 2000s, Minas Gerais' legislative body, based on what was allowed by the 1988 Constitution $^{9}$, decided to resume the metropolitan issue by re-instituting the RMBH and approving a new structure of metropolitan planning and management, which includes social participation through the deliberative Metropolitan Development Committee. We will not describe here this new structure ${ }^{10}$, but we'll just say that it allowed the emergence of informal stakeholder organizations that can be characterized as embryos of social control over metropolitan planning and governance in a process beyond official participation. One of them is the Metropolitan Collegiate (Colegiado Metropolitano), a committed group of stakeholders formed by 30 members representing organized Civil Society: entrepreneurs' organizations, NGOs, professional associations and universities, workers unions, and grassroots organizations, covering a wide range of different metropolitan issues. It is responsible for appointing - and giving technical and political support to - the two representatives of civil society who sit in the Metropolitan Development Committee ${ }^{11}$. The Collegiate also plays an important role as a forum for discussing and proposing ideas for both research and governance in metropolitan planning and management process. The Metropolitan Development Committee is so far only beginning to fulfil its role in metropolitan planning decision, as many important projects and investments for RMBH were decided in other state instances.

9 The 1988 Constitution changed from federal to state governments the right to create and manage their metropolitan regions.

10 RMBH's new metropolitan structure (Arranjo Metropolitano) can be consulted on www. rmbh.org.br or www.agenciarmbh.mg.gov.br

11 The Metropolitan Development Committee is so far only beginning to fulfil its role in metropolitan planning decision, as many important projects and investments for RMBH were decided in other state instances. 
This initiative and the actions of several civil society and public bodies - including UFMG - are promising attempts to create a process of participatory planning and social control at metropolitan level. The development of both PDDI and MZ was based on a critical perspective, introducing an innovative inter(trans)disciplinary approach and the creation and/or reinforcement of participatory processes, rethinking and transcending the relatively consolidated principles of the urban reform begun in the 1980s. The PDDI introduction text reads:

[T] he critical approach supersedes the analytical and functional meaning of reformist planning, not disqualifying it, but limiting it to its immediate, operational character; it goes beyond with the objective of apprehending totality in transformation and seeking to build processes aimed at a social, economic and environmental transformation, while searching for contemporary solutions for regulation, investment decisions, forms of social organization that favour diversity, and the construction of emancipatory social processes. (UFMG/Pucminas/UEMG, 2011, p. 5, our translation).

The idea is that this new, innovative and participative planning process might help to create a sense of continued metropolitan planning and generate a sense of metropolitan citizenship as a means to construct a "project identity" that appears, in Castells" words, "when social actors, on the basis of whichever cultural materials are available to them, build a new identity that redefines their position in society and, by so doing, seek the transformation of overall social structure" (Castells, 1997, p. 8).

Such a statement may be seen much more as a belief than a concrete and sound possibility. However, it has been supported by embryos of social practices - including the continuous involvement of UFMG in this planning process - capable to contribute with alternatives aimed at radical sociospatial changes, as it will be discussed below.

\section{Metropolitan planning: an innovative academic experience}

Planning, taken as an academic practical experience, is itself a challenge. The critical approach implied in the academic practice must be at the center of the guidelines of any planning effort, which is rather innovative and difficult, given the necessary involvement of the many diverse actors that are playing the game of organizing the city-region, in our case, the RMBH. 
On the other hand, there is a current tendency to look at urban (metropolitan) planning as a strategic operation geared by the State to attract possible investments by real estate capital in particular, but also contemporary technological services and industries. The strategy usually relies on major urban projects to act as references to modernization and gentrification processes in chosen urban areas of global interest. Beginning with Barcelona experience, several others have followed, from Bilbao to Rio de Janeiro. In such a planning perspective, interventions should skip a comprehensive approach and instead, focus strategically and operationally on those areas that induce transformation in the urban fabric as a whole.

In UFMG's metropolitan planning experience, it was decided from the very beginning that it was necessary to go beyond the analytical and strategic approaches without disregarding the operational dimension, as cited above. It meant adopting a totalizing transdisciplinary approach to construct a critical perspective on the metropolitan region, both in its internal and external dimensions, and at the same time be as specific as possible in identifying the major policies, their internal programs, and eventually, when viable, preferential projects to be implemented in the short, medium (2023) and long run (2050).

This had to be explicit since the very beginning of negotiations with the Metropolitan State Sub-Secretary to emphasize that the university would not be interested in working in a planning process based on the maintenance of the status quo. Instead, given the unacceptable socio-economic and political inequalities in Brazil, certainly reproduced in the RMBH, metropolitan planning had to necessarily be 'planning for transformation' politically, socially, economically and environmentally - or else it would not be. Therefore, concerns about establishing a truly participatory planning process in Belo Horizonte Metropolitan Region (RMBH) have guided UFMG's planning team since 2009, when PDDI was designed.

Theoretically, our main references were Henri Lefebvre's writings on 'the right to the city' and 'the urban revolution', among other of his works (Lefebvre, 1969; 1999; 2008), mostly assuming that we are now at the beginning of an 'urban age' in which collective reproduction prevails over the 'industrial age', and a new politicization of space is in the process of redefining sociospatial relations within the city-region.

On the other hand, we drew intensely from John Friedmann's planning traditions based on 'social learning' and 'social mobilization', in an 
attempt to overcome the 'social reform' tradition that has characterized urban and regional planning since last century and throughout most of Brazil's planning experiences.

Such a critical approach implies accepting contemporary horizontal relations involving the technical body, represented by UFMG team and state and municipal technicians, and the population impacted by the planning process. It also necessarily means to consider that the technoscientific knowledge is equivalent in importance to the knowledge that emanates from everyday life and practices. ${ }^{12}$ The participatory process has thus to incorporate those principles if they were to match our theoretical and political concerns when engaging in a planning process of such a scope and dimensions.

It is always important to reemphasize the fact that this was/is a process carried out within and by the university, which in itself is not common, and quite challenging. As a university activity focused on extension, it privileged a strong university-society interface, represented by a wide participatory process that promoted workshops and seminars, theatre plays, flyers, booklets, internet access to data, reports and work-in-progress material. As a result, there was close involvement of faculty, researchers and students both graduate and undergraduate from different disciplinary fields with social movements, municipal civil servants and council officials, state government officials, activists, and citizens in general. ${ }^{13}$ Such approach aimed at bridging gaps between technical/academic knowledge and everyday experience and practices, an attempt to put the notion of knowledge ecologies into practice, as proposed by Sousa Santos (2007a), which were central to achieve more accurate understanding of local processes, and for the design of some policies and programs.

In fact, the first $\mathrm{PDDI} / \mathrm{RMBH}$ planning document states quite clearly not only those above mentioned approaches, as seen, but also the fact that the proposed planning process had as its central objective and priority to produce knowledge to inform non-alienated 'metropolitan citizens' committed with their life-spaces. The ultimate objective is to contribute for

12 In this case, Boaventura de Sousa Santos is a major reference, particularly his books about the critique of modern science and the advent of a post-modern science (2003; 2005).

13 The participatory process of the Metropolitan Plan accounted for around 3000 participations and 610 institutions/organizations; The MacroZoning process involved 1120 participants. 
social emancipation through a permanent participatory planning process, eventually changing the population (particularly, their organized sectors) from 'objects of planning' into 'subjects of planning'.

From a university viewpoint, the main principles for this planning experience were to adopt a critical contemporary approach in studies and proposals, whereby notions of totality, mobilization and social learning (Friedmann, 1987) become central elements in the planning process; to understand planning as a means to achieve social, political, economic and environmental transformation; to accept social engagement as a key political strategy to strengthen everyday knowledge, collective action and life space in order to build a feeling of metropolitan citizenship aiming at social emancipation.

Today, after seven years working at the metropolitan level while searching for effective popular participation, this team has produced significant knowledge and a large experience of planning in social learning and mobilization. Some instances of political participation have been created at local, metropolitan and state levels which have kept on experimenting new popular and institutional forms of social, cultural and political mobilization to pursue our goal of establishing an emancipatory planning process in RMBH. Among them, we will present LUMEs, the most decentralized and popular form of socio-political participation achieved so far, open to a myriad of possibilities.

LUMEs - Locales of Metropolitan Urbanity (Lugares de Urbanidade Metropolitana) - are one of the mechanisms that have been tried to be enforced as a new local and metropolitan process of permanent participation and engagement of those populations. LUMEs - a program proposed within PDDI's Policy of Democratization of Public Spaces - represents an attempt to include the academic world - faculty and university students within Belo Horizonte's metropolitan planning process.

The idea of LUMEs Program stems from a federal program created by Lula's Minister of Culture, Gilberto Gil, in 2004, called Live Culture (Cultura Viva) ${ }^{14}$, within which a project named Pontos de Cultura (Culture Places) created a network of localities to promote popular culture, from residences to community organizations, as "anthropological do-in points to activate Brazil's social body" (Gil, 2003). 
LUMEs were proposed and created as places where both techno-scientific and popular knowledge are to be produced and exchanged, with the participation of local communities, municipal and state technicians and politicians, and university students and professors. They also focus on the strengthening of cultural groups attempting to create opportunities in social, popular and solidarity economics, urban-rural agroecological experiences and other forms of community organization for production and consumption. It is also an educational experience both within the university and communities, in which students participate and support local initiatives, in a pilot experience of 'metropolitan internship'. It has become an extension project and a regular course at undergraduate level at $\mathrm{UFMG}^{15}$, involving students from various departments in theoretical discussions and practical experiences in those LUMEs already in process of organization in RMBH's municipalities.

LUMEs began with municipal public libraries and evolved to include different groups working with community libraries (Biblioteca Diadorim, in Vespasiano) and community weekly food and crafts fairs (Feira Saia da Linha, in Vespasiano); a group of youngsters organized around abandoned watertanks (Casulo), elders working with craftsmanship in Ribeirão das Neves, municipal cultural centers (Matozinhos), community centers such as Casa de Gentil (Raposos), among others.

Now, within the process of revision of metropolitan municipal master plans, the eleven municipalities have created a Planning Space (Espaço do Plano Diretor), both physical and virtual, where representatives of the municipal legislation and governing branches and the civil society were organized to interact with UFMG team accompanying the planning process. These places are meant to continue as LUMEs after the planning revision ends, next year, with the creation of the "metropolitan internship" as a permanent process of participation of professors and students in the local planning process

It certainly does not respond to all contemporary needs for strengthening popular participation or organization of civil society around social

15 The course was first offered in the first semester of 2016 involving 32 students from 12 different departments at UFMG, conducted by Clarice Libânio and Júnia Ferrari. It has been offered every semester and students have a theoretical introduction and a practical experience working with LUMEs already in process of organization in different municipalities in $\mathrm{RMBH}$ such as Raposos, Matozinhos, among others. It will now be also offered in the School of Economics, geared to LUMEs that are being created in the eleven municipalities where UFMG team is currently involved in the revision of their Master Plans. 
control of planning processes, but it is believed to open new windows to the steady commitment of the university. The expectation is that it may also represent a pilot project for other universities in $\mathrm{RMBH}$, and eventually and hopefully, for other areas in the country.

\section{The environmental dimension transforming metro- politan planning and shaping territorial restructuring}

As mentioned above, the making of a metropolitan planning process for Belo Horizonte contains a number of innovative approaches and practices that deserve attention for their reassertion of planning as a process capable of involving different sectors of the population, and also by the way in which some knowledge areas of analyses and intervention were dealt with in such a process (UFMG/Pucminas/UEMG, 2011; UFMG, 2015).

Some attempts to establish a close dialogue involving urbanization, nature and culture through planning are highlighted next, arguing for its potentially innovative methodological and processual approach. Beginning with PDDI and following throughout MacroZoning, these concerns were finally materialized in the proposition of a green and blue weft (Trama Verde Azul - TVA), as will be seen below.

This process brought back the metropolitan level and its articulation to local levels to the planning debate, an issue for decades lost in the realm of constitutional reassertion of local power, usually understood as municipal power. To acknowledge territorial planning, particularly land use planning, as a municipal right, and in so doing to promote trans-boundaries debates and mutual understanding of common questions among municipalities seems to be at the same time a major challenge and a necessary move towards reinventing contemporary democratic planning at metropolitan level. It is worth recalling that the trajectory of urban planning in recent years has in a certain sense overestimated the importance of municipal (urban) level for which several planning instruments were proposed, particularly within the Statute of the City, although without much success. The proposed alternative to excessive localism was to incentive agreements and consortium initiatives among municipalities to solve common issues.

In this sense, the definition and assessment of a zoning category of "metropolitan interest", used as a basis for the Metropolitan MacroZon- 
ing proposal, proved to be a very interesting example as an exercise to face such challenge. The ZIM - Metropolitan Interest Zone - was the basic territorial unit expressing areas in which metropolitan interest was recognized as prevailing over local ones. What is or around what issues was metropolitan interest defined? Based on collaborative mapping in workshops the participants identified such areas all over the region. The relevant issues justifying them were, not surprisingly, the main road axis where services, commerce and infrastructure were provided, but also, and in emphatic ways, the areas recognized by their environmental and/or cultural importance. Watershed areas responsible for metropolitan water supply; environment protection units such as parks, food production areas, mountains recognized as natural heritage; cultural equipment such as museums; among others, regardless of their location within the metropoli$\tan$ region. ${ }^{16}$

In the same direction, PDDI was conceived as an integrated set of conceptual references around which policies, programs and projects could be negotiated and developed by those who participated in the process. It was not a finished normative document in itself, although some policies could be immediately applicable while other required further developments. In practical terms the group worked within a methodological scope which meant to be both inter-sectorial and inter(trans)disciplinary. The studies were carried out around ten thematic areas, each maintaining a simultaneous social, economic and environmental approach that avoided replicating traditional ways in which public sectorial policies are conceived and implemented in state secretaries or committees. ${ }^{17}$ Each proposed policy was also understood in its territorial and institutional dimensions, and contained several programs which, in many cases, unfolded into specific projects and short term actions. In the end, the PDDI resulted in the formulation of a

16 Social housing and popular areas requiring urban upgrading were also mentioned as potential areas of metropolitan interest, inasmuch as commuter workers produce wealth in different municipalities, but such interpretation of metropolitan interest was not widely accepted.

17 The thematic study areas were: Urban mobility, public transportation, roads system; Land use, real state dynamics, metropolitan centralities; Everyday life, housing, life quality; Culture, education, food security, work and income; Health, environment, sanitation, water resources; Cultural and environmental complexes; Institutional planning capacity, municipal governance; Socio-environmental risk, vulnerability, public security; Demographic and environmental aspects of social demand; Productive structure, knowledge, technology and energy alternatives. 
major territorial restructuring proposal, related to the development of an institutional basis required for the implementation of proposals, and the creation of twenty-eight policies (and more than eighty programs) articulated within four transversal thematic axes: accessibility, security, sustainability and urbanity. They represented the visions of the future, the utopia for the metropolis, as collectively crafted and agreed along the participatory discussion process.

Within this methodological scope, the environment emerged as a central issue, permeating the Plan in its different phases, bringing to the forefront the discussion of a process of urbanization in which nature is conceived and perceived as part of the process of production and appropriation of space; and not as its opposite, in which the logic of urbanization and urban expansion seeks to integrate - and protect - empty, unbuilt, rural, natural, agricultural areas as part of a larger, integrated space of social reproduction.

On the one hand, the usual environmental areas occupied an important place within the PDDI as important study fields that generated several policies related to sanitation; water supply; flood and risk prevention and control; garbage collection, disposal and recycling; reinforcement of environmental protection units; articulation with existing watershed policies; introduction of ecosystem services approaches and policies related to energy saving and low-carbon emission.

On the other hand, within such policies it is worth pointing out that there was a systematic methodological effort to look at urbanization from the view point of urban waters, which requires an ontological turning point in the usual way of looking at (and theorizing about) the urbanization process, that is, from the perspective of landed (and almost always private) property. To give visibility and restore urban rivers and creeks, protecting their sources and recharge areas or controlling flood areas are important elements to rethink land use proposals and parameters. In the context of Brazilian peripheral urbanization, the treatment of risk and flood urban areas comes hand in hand with slum upgrading and social housing policies, as shown by the results of a successful environmental restoration program of the municipality of Belo Horizonte since the 1990s ${ }^{18}$.

18 DRENURBS - Programa de Recuperação Ambiental de Belo Horizonte - a municipal environmental restoration program for rivers and creeks which were still in their natural beds - whose principles could be adopted by other municipalities in the metropolitan region. The 
As one of its principles, the PDDI attempted to consider economics and ecology studies and propositions together, reinforcing the sustainability of society's productive basis. Besides that, some policies related to social, solidarity and popular economics were designed to stimulate actions aiming at reducing social inequalities and promote development alternatives from below. Among those it is worth mentioning some policies associated to small scale agricultural production, which articulates food security, agroecological use of land, urban agriculture, cultural values, water sources protection, with potential of contributing to social and economic emancipation (Almeida, 2016). One decisive argument is that growing food or putting empty land into common use is a contemporary way of fulfilling the constitutional principle of the social function of property (land), which is basic for the notion of right to the city.

Following that same principle, mining activities, an important basis of the metropolitan economy, generated a specific policy for mining territories, which attempts to stimulate social and environment commitment by mining companies with their places of exploitation. Such proposal was conceived at a time when a strong socio-environmental movement opposed the installation of a large scale mine - Mina Apolo - eastern from the metropolitan region in clear conflict with important water sources, biodiversity conservation and rural/traditional settlements livelihood. The movement was successful in achieving the creation of a park - Parque Nacional da Serra do Gandarela - in part of the original area intended for mining exploitation, and proved that nature as a common asset/use value, and particularly water sources for widescale use, is a powerful driving force to unite different social movements. ${ }^{19}$

Those two examples highlight some of the challenges posed to metropolitan planning in its effort to articulate adequate conditions of attraction and reproduction of the hegemonic productive capital - mining, property development, advanced services - with actions that reinforce, protect, and give visibility to small scale collaborative local and micro-regional activities - agriculture, crafts, services, among others.

program aimed at water depollution, flood risk reduction, water resources integration with the surrounding urban settlements (usually informal and poor), quality of life improvements, and valorization of the urban environment centered on natural water resources. Population involvement in all phases, including maintenance of the designed linear parks along the rivers, was a basic assumption of the program.

19 See Coelho-de-Souza (2015) and www.aguasdogandarela.org. 
The territorial restructuring proposed by the PDDI encompasses some of those elements in its main conception, which proposes to change the territorial structure from a classical center-periphery structure combined to scattered urbanization, to a network of multilevel centralities connected by a multimodal mobility infrastructure network. After the main centrality, the metropolitan capital Belo Horizonte, three other centralities were proposed in the north, west and south axes of expansion. They are either existing or potential concentrations of commerce, work, services, cultural and social equipment, housing and leisure. They aim at bridging the gap between centre and periphery, reinforcing the local urban structure, and ideally diminishing the need for commuting ${ }^{20}$. In such an ideal territorial restructuring, urbanization is contained but also extensively developed through the metropolitan territory in multiple centralities; vacant land and buildings are intensively occupied, while other land uses - agriculture, leisure, protection, permeable, tourism and culture - overlap and interconnect with and within urbanized areas, redefining conceptually and politically the formal administrative divide between rural and urban areas.

The adoption of a green and blue weft - Trama Verde e Azul (TVA) as a central MZ proposal of territorial restructuring based on the social appropriation of nature and culture represents, in our view, a conceptual turning point, an innovation in metropolitan planning in the Brazilian experience. It evolved from the principle in which any planning process should lead to social, environmental, economic and territorial transformation, encompassing those elements that were already designed in many metropolitan policies as mentioned, and it actually gained shape in the process of discussion of the categories to be used in the Metropolitan MacroZoning process and in the definition of metropolitan interest.

The TVA was inspired by the French experience of the trame verte (et bleue), originally a network of green infrastructure, ecological corridors associated to the water basin planning network. The TVA principles were adopted in a number of successfull European regional planning and environmental/economic recovery experiences, particularly in places expe-

20 It is interesting to note that such proposal may generate competition between localities and have impacts over eventual increase in land prices. An example of market-oriented appropriation and capture of the concept by landed capital is the claim by a major private upscale development project, to become the southern metropolitan centrality, arguing to follow the PDDI guidelines. Such claim, in our view, contradicts the notion of reinforcing diversity and mix of incomes and activities attached to the concept of centrality. 
riencing severe degradation such as former decaying mining areas. The proposal, still to be further developed, for Belo Horizonte Metropolitan Region intends to become a referential set of principles to be discussed, adapted and adopted by the social agents that produce and use the metropolitan space. ${ }^{21}$ It is composed by the articulation over the territory of many elements, such as (i) the existing green infrastructure - parks, protected areas, agricultural areas, biodiversity reserves, green spaces, natural monuments, geological heritage, ecological corridors and other potential green areas; (ii) the blue infrastructure of rivers, lakes, creeks, water sources, underground water reserves, flood plains and other elements associated to the centrality and maintenance of water as common regional use value, including the existing water governance structure; (iii) a large array of cultural and natural manifestations and heritage - museums, cultural equipment, historical and cultural settlements, libraries, traditional populations, villages, places popularly used and recognized for their cultural values, etc; (iv) places related to ecological tourism and cultural policies; (v) areas of urban ecological agriculture and small scale processing of food and crafts, among several other communal uses of the metropolitan territory.

The intention with the adoption of TVA is to promote the articulation and interweaving of all those elements, in different spatial scales, to form networks of connections between natural and built spaces, protecting and recovering the ensemble of social space, reducing impacts of industrial, conventional agriculture and property development activities, reducing socioenvironmental risks, increasing green and leisure areas, promoting economic and urban activities compatible with preservation of nature, creating and transforming a network of multimodal mobility connecting natural areas with urban centralities, among many other possibilities.

In short, the TVA broadens the meanings of the proposed territorial restructuring associating the production of abstract space with the appropriation of social spaces at metropolitan level. As such, the political and institutional articulations to make it happen are still to be invented, but will certainly influence metropolitan and local policies. The main ideas were widely discussed in workshops during the MacroZoning project and although containing a substantial level of abstraction, the proposal was rapidly understood and people got immediately seduced by it. It consti21 See Eleutério et al. (2015) and Euclydes (2016) for initial assessments of the adoption of TVA in metropolitan planning process. 
tutes a utopia of the future, bringing nature and culture as central to the process of production of space, recognized as a source of learning, to be appropriated and transformed by society through everyday life.

Finally, it is worth saying that such innovative and utopian approach was possible as it was developed within the university, resulting from a transdisciplinary vision, free and critical knowledge, and creative thought from its faculty and students together with the population itself, who contributed immensely with discussions and propositions in the participatory process. The TVA proposal was not part of the contract with the metropolitan agency, but it may evolve towards an ontological reversal in planning theory and practice in the Brazilian experience.

\section{Forward and back again: revisiting practical experience, seeking theoretical meanings}

As previously described, the involvement of the University with the process of metropolitan planning, as a social and political practice, resulted in outcomes far beyond initial expectations. In fact, none of them could have been theoretically anticipated - what reinforces the defense of an ongoing and ever unfinished methodology of work and research that leaves openings for creative possibilities not yet foreseen. Since practice alone is never enough to construct ways of radical changes, a new moment of theoretical and critical reflection is required, i.e., a moment to look back at the process and try to understand the reach and give meaning to the new elements.

In this sense, this final section attempts to condense the experience and to highlight some of the possibilities - practical and theoretical - that is believed are being gestated in the process of metropolitan planning in Minas Gerais. It is unnecessary to say that, consistent with the idea that planning is mainly a political, rather than a technical process, these possibilities are not discoveries, but political agendas to be fought for, i.e., they are not guaranteed outcomes, but the result of social and political disputes. They are concrete utopias that hopefully may become reality based on a radical transformation of the processes of production of urban/metropolitan space and, therefore, of planning itself.

The relationship between planning practice and the university is transforming both of them, reasserting a political role for the university (instead 
of a neutral "scientific" one). Our aim is not to act as a service provider for the state - especially the bureaucratic-technical knowledge that the state usually demands - neither to become simply a repository of technical information and modern scientific reason. To turn planning into a political process one must go beyond the participation of civil society (even a "qualified one"); a space for its involvement in its own terms must be created. The political role that the university is trying to play is exactly to provide and stimulate this kind of space. ${ }^{22}$

This implies a critique of traditional planning and of the traditional relationship between university and society. In fact, the university is trying to open the possibilities for a radical break with alienated everyday life, i.e., the political action of the university must not be concerned with the management of a depleted everyday life but with its transformation. To fully understand this new moment, it has to be emphasized that the university introduced itself in a system of metropolitan planning that was divided between the state (in two different levels) and the civil society. But it did not get into this system to be only a support apparatus; the university became an active actor wishing to affect this field of interactions with its own project for the metropolitan region. In this sense, the university assumed a new stance over its extension role, refusing to be only a translator or an intermediary.

The main innovation is, perhaps, an epistemological one. In order to assume this radical political role one has to rethink how to produce knowledge and how are the expectations over its impact on society. Although departing from the methodological proposal of social learning, by John Friedmann (1987) - which questions the superiority of the so-called technical and scientific discourse recognizing the importance of grassroots production of knowledge - we believe that we were able to go beyond it. As said before, this paper is not trying to translate the concepts, ideas and demands that arise from civil society to a rational and technical language for the state, or, the other way around, to interpret legal and technical

22 It is important to highlight the possibility that the university also becomes a sort of constraint to autonomous processes of production of space. The optimistic approach developed below may not blind us to the fact that the university is also a modern institution that has its own logic of production of knowledge and of production of subjects of knowledge. Therefore, in order to become a space of radical politics, the university itself - it is never enough to emphasize - must also pass through a process of transformation of its own nature. This is only one dimension of the various limits not completely explicit in the argument that follows, but we have to remain aware of their existence. 
categories from state planners to the common people. Instead, it started to recognize that between one and another there is something untranslatable, something incommensurable. If one does so, the problem of incommensurable epistemologies becomes also a political difficulty, because either some wishes and demands cannot find echoes in the traditional categories of planning or they are oppressed for having to fit into them and be half represented. ${ }^{23}$

Therefore, the task imposed upon us, and we have been dealing with it as we go, is to bend the traditional categories of planning, if not fully changing them into something totally different, and transform them into something with power to mobilize different groups of people around a new project for the production of metropolitan space. This sometimes means that new categories cannot immediately be put into practice because what is under dispute are not only ways of seeing and saying about the production of space, but also, and more decisively, other forms of doing.

It may sound like an abstract debate, but it is actually based upon some concrete experiences. The involvement and the appropriation by civil society of categories such as "metropolitan interest" or, even more clearly, of the idea of a metropolitan space articulated from a TVA perspective are strong signs of that. In the case of TVA, it is important to notice how it became a concept that brought together different actors and projects around an alternative proposal of metropolitan territorial restructuring. The TVA gave new strength and a metropolitan perspective to a variety of once marginalized actors and projects for the RMBH, expressing and condensing different struggles in a common ground. TVA not necessarily is translated into a category of planning - as zoning, for example - but rather represents a new form of production of metropolitan territory that could become real regardless of any process of traditional planning. As a process of production of space, it does not have to become a plan, it does not have to have delimited borders, specific parameters etc. This process of creating collectively a new "grammar" that represents a project for the metropolitan region in-

23 This kind of perception arises especially in working groups with civil society on the participatory stages of the development of projects such as PDDI and MacroZoning. In these opportunities we developed a methodology that seeks to give people the opportunity to say in their own terms what they know about their own territory and which are their desires. In doing so, more often than not, we discovered new ways of producing the space that were otherwise invisible. But we also discovered desires and perceptions of the territory that were not compatible with the planning categories that we were working with, creating a hiatus between the actors of the territory and the planning narrative about it. 
stead of using the old and traditional categories to half-express ourselves finds echoes in the hearts and minds of common people that have also their own utopias for RMBH. Utopias that are being built collectively.

This conclusion is put forward by working in, and also reinforcing, a possible different model of university and of production of knowledge. The construction of new political subjects has its counterpart in the deconstruction of privileged positions of knowledge. While proposing that for the planning process, we also practiced it inside our own team as we collectively prepared the process inside the university. A rather anarchic, transdisciplinary and never finished methodology reflects that, and it is probably a powerful way to do it. The recognition of the possibility of other epistemologies and ways of seeing the world has a lot to do with the radical transgression of the myth of the inherent superiority of technical knowledge and of its subject owner. It is based upon a critique of a privileged space of speech that would be more rational and reasonable than others. This deconstruction - which in many ways is our own deconstruction and a process of learning for the university itself - became an ontological imperative. It affects not only the way the world is acknowledged, but also the ways one acts upon it and the way one conceives it to be possible (and therefore, practical). It offers at least the openings to think about practice outside the boundaries imposed by the bureaucratic, formalistic and legal language of traditional state's planning. In this sense, "transdisciplinarity" is more than a communication between different branches of scientific knowledge, but a dialogue between different epistemologies and "wisdoms" that defies an analytical "qualified discourse" about urban space, and gives voice and legitimacy to former marginalized political subjects. Radical epistemology helps to build and rescue a perspective of radical politics into planning, especially by bringing into light some of the disagreement points in a "dissensual" perspective as advocated by Jacques Rancière (1996a; 1996b).

All that leads to the problem of how these other epistemologies can be expressed; how can other practical possibilities become reality; how can we find the right words for our utopias? Once again, the traditional path was closed. When it is time to put our dreams into some language one finds more friction than convergences with the categories of traditional planning. Therefore, the university has more to do than legitimizing discourses and political subjects; it has to empower them to create their own 
symbolical field. The university could, therefore, be the space - and not the only protagonist - where these new languages, these new ways of seeing and making the world could be gestated; ways of seeing and making the world that go far beyond the language of capital, of abstract space, of the bureaucratic state, which are ways of seeing certain things and not seeing others (or seeing them in a particular and distorted way). That is, to make up concepts, categories, to support other rationalities, other metaphors, others poetics, other narratives that could embrace and truly represent the new voices that we wish to bring to the politics of planning in a critical perspective; to make up forms of seeing and making that are coherent with our utopias. It is about making up concepts that express our utopias without necessarily being attached to the already existing traditional categories that delimitate the real and the possible; without a commitment with a form of practice that only reproduces alienated and colonized ways of seeing and making urban/metropolitan space. Summing up, it is possible to say that our university team has understood the political strength of symbolical production. This symbolical production, however, is not imposed by the university - although it plays an important role - but has to depart from the same political subjects that we intend to give voice to. In this sense, the existence of a space where these subjects can develop their autonomy and raise their own perspective is crucial. LUMEs are thought to be such spaces designed for the free appropriation of new political subjects and the articulation of new perspectives for the metropolitan region. A space of production of collective knowledge articulated with everyday life and expressing the interest and projects of metropolitan actors in their own terms. A space for collective cultivation of utopias.

The university as we experience it is becoming a territory of utopia, or at least a territory open to the production of utopias. And a specific form of utopia: not the one that dreams with a future where all our problems will be solved in a technological panacea of some smarter city, but a utopia that is imagined from the critical break with the present conditions of production of space, from a radical transgression - almost a profanation, to recover the term by Giorgio Agamben (2007). To make it clearer we could put it in Boaventura de Sousa Santos' terms (2007b): we are not committed to an abstract and homogenous future, but to the possibilities of alternative futures that arise from the expansion of the experiences hidden in the alienated everyday life of the present. It is really about shrinking the per- 
spective of the future in order to expand and to enrich our perspective of the present; to try to make visible all the possibilities that are marginalized by the categories that are intrinsically connected to only one view of the future (not by accident, one that coincides with the undetermined and unsustainable expansion of capital); to try to bend the parameters by which we judge what is possible and impossible. When present experiences are expanded we are able to see other possibilities, other ways of seeing and producing urban space, and other political subjects that were only treated so far as objects of planning. We trade a quantitatively huge opportunity in the future for a shorter perspective, but one that is qualitatively enriched. But the traditional categories and practices are not conceived in this perspective, so we need a breaking point, a critical overcome. The university accepted this challenge of rethinking planning as practice and as theory - a project not yet finished, but already glimpsed and sought - in order to expand our perception of the present and to be able to see the possibilities of other ways of producing and appropriating metropolitan space. In doing so, the university becomes - in theory and in practice - a space for utopia and for radical politics that embraces the contradictions and the multiplicity of actors in the production of space. It is precisely this utopian dispute that best characterizes the political-epistemological role of the university in the process of metropolitan planning in Minas Gerais.

\section{References}

AGAMBEN, G. Profanações. São Paulo: Boitempo, 2007.

ALMEIDA, D. Isto e Aquilo: agriculturas e produção do espaço na Região Metropolitana de Belo Horizonte (RMBH). Belo Horizonte: Universidade Federal de Minas Gerais, 2016. Tese (Doutorado em Geografia).

AZEVEDO, S.; RENNÓ, V. Dilemas da gestão metropolitana em Belo Horizonte. In: MENDONÇA, J. G.; GODINHO, M. H. de L. (Orgs.). População, espaço e gestão na metrópole: novas configurações, velhas desigualdades. Belo Horizonte: Editora Pucminas, 2003.

CASTELLS, M. The power of identity. Oxford: Blackwell Publishers, 1997.

COELHO-DE-SOUZA, C. O espaço da resistência: uma construção teórico-prática inspirada em Henri Lefebvre. In: COSTA, G.; COSTA, H; MONTE-MÓR, R. (Orgs.). Teorias e práticas urbanas: condições para a sociedade urbana. Belo Horizonte: C/Arte, 2015.

ELEUTÉRIO, J.; NASCIMENTO, N.; COSTA, H.; MOURÃO, A.; MALTA, G.; LEITÃO, R.; LEMOS, R.; ALMEIDA, D.; TUPY, I.; MELGAÇO, L.; ARAÚJO, F.; FARIA, D.; MONTE-MÓR, R. Conciliating urban development with water resources protection in 
Brazil through the conception of a "trama verde e azul", green-blue network, as an urban planning framework. In: Water, megacities and global change Conference, 2015, Paris. Proceedings... Paris, UNESCO, 2015.

EUCLYDES, A. C. P. A hipótese otimista. Belo Horizonte: Universidade Federal de Minas Gerais, 2016. Tese (Doutorado em Arquitetura e Urbanismo).

FRIEDMANN, J. Planning in the public domain. Princeton: Princeton University Press, 1987.

GIL, G. Discursos do Ministro da Cultura Gilberto Gil. Brasília: Ministério da Cultura, 2003.

Disponível em: http://www.cultura.gov.br/discursos. Acesso em 22/01/2017.

LEFEBVRE, H. O direito à cidade. São Paulo: Editora Documentos, 1969.

LEFEBVRE, H. A Revolução Urbana. Belo Horizonte: Editora da UFMG, 1999.

LEFEBVRE, H. Espaço e Política. Belo Horizonte: Editora UFMG, 2008.

MINISTÉRIO DA CULTURA. Programa Nacional de Cultura, Educação e Cidadania - Cultura Viva. 2004. Disponível em: http://culturaviva.org.br/programa-cultura-viva/. Acesso em 22/01/2017.

RANCIÈRE, J. O desentendimento: política e filosofia. São Paulo: Ed. 34, 1996a.

RANCIÉRE, J. O dissenso. In: NOVAES, A. (Org.) A crise da razão. São Paulo: Companhia das Letras, $1996 \mathrm{~b}$.

SOUSA SANTOS, B. Introdução a uma ciência pós-moderna. 4 ed. Rio de Janeiro: Graal, 2003.

SOUSA SANTOS, B. Um discurso sobre as Ciências. 13ª ed. São Paulo: Cortez, 2005.

SOUSA SANTOS, B. Para além do pensamento abissal: das linhas globais a uma ecologia de saberes. Novos Estudos 79. São Paulo: Cebrap, 2007a.

SOUSA SANTOS, B. Renovar a teoria crítica e reinventar a emancipação social. São Paulo: Boitempo, $2007 \mathrm{~b}$.

UFMG. Projeto do MacroZoneamento Metropolitano - MZ-RMBH. Belo Horizonte, 2015.

UFMG/PUCMINAS/UEMG. Plano Diretor de Desenvolvimento Integrado da Região Metropolitana de Belo Horizonte - PDDI-RMBH. Belo Horizonte, 2011.

\author{
About the authors \\ RobertoLuís de Melo Monte-Mór - monte-mor@cedeplar.ufmg.br \\ Professor do Cedeplar/FaCE/UFMG, Belo Horizonte, Minas Gerais. \\ Geraldo Magela Costa-gemcosta1@gmail.com \\ Professor do Instituto de Geociências/UFMG, Belo Horizonte, Minas Gerais. \\ Heloisa Soares de Moura Costa - hsmcosta@ufmg.br \\ Professora do Instituto de Geociências/UFMG, Belo Horizonte, Minas Gerais. \\ Marcos Gustavo Pires de Melo-marcosgustavo@gmail.com \\ Doutorando em Economia, Cedeplar/FaCE/UFMG, Belo Horizonte, Minas Gerais.
}

This paper is connected to the development of PDDI - Integrated Development Metropolitan Plan - and its MacroZoning Project by a group of faculty, researchers and students from UFMG. It is also articulated to Projeto FAPEMIG/Conseil Régional NPDC - APQ-03544-15, "Wealth Through Sharing - Riquezas Compartilhadas".

\title{
About the article
}

Submission received on March 02, 2017. Approved for publication on June 13, 2017. 